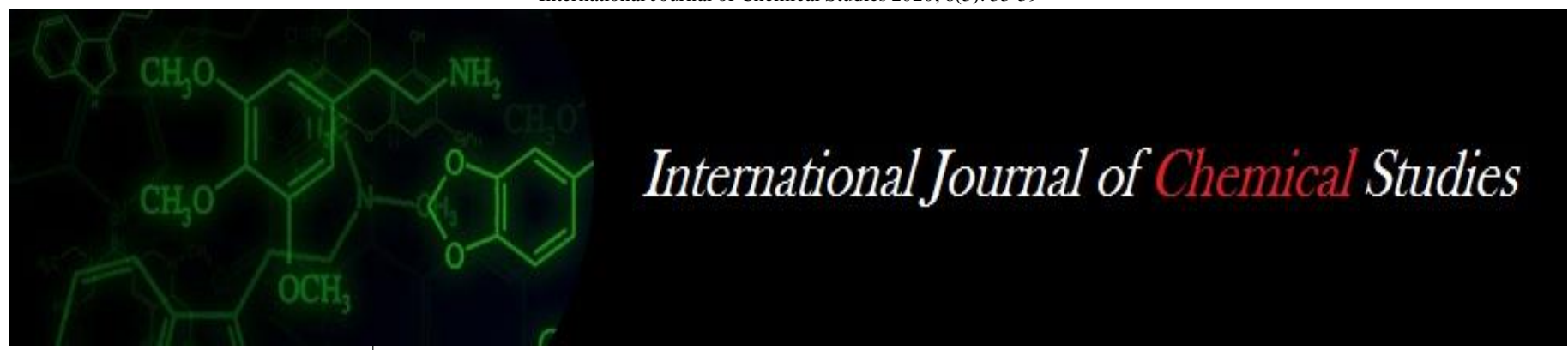

P-ISSN: 2349-8528

E-ISSN: 2321-4902

www.chemijournal.com

IJCS 2020; 8(3): 33-39

(C) 2020 IJCS

Received: 18-03-2020

Accepted: 20-04-2020

Olayinka A Oyetunji

Department of Chemistry,

University of Botswana, Private

Bag UB, Gaborone, Botswana

\section{Ruth Gontse}

Department of Physical and Chemical Sciences, Botswana University of Agriculture and Natural Resources, Private Bag, Gaborone, Botswana

Florence M Nareetsile Department of Chemistry, University of Botswana, Private Bag UB, Gaborone, Botswana

Corresponding Author: Olayinka A Oyetunji Department of Chemistry, University of Botswana, Private Bag UB, Gaborone, Botswana

\section{Substitution kinetics of platinum N,N, N', N'- Tetrakis (2-pyridyl methyl) octane diamine aqua complex with thiourea, glutathione and L-cysteine nucleophiles}

\author{
Olayinka A Oyetunji, Ruth Gontse and Florence M Nareetsile
}

DOI: https://doi.org/10.22271/chemi.2020.v8.i3a.9460

\begin{abstract}
The ligand substitution kinetics of the platinum(II) complex, $\left[\mathrm{Pt}_{2}(\mathrm{~L})\left(\mathrm{OH}_{2}\right)_{2}\right]\left(\mathrm{ClO}_{4}\right)_{4}\left(\mathrm{~L}=\mathrm{N}, \mathrm{N}, \mathrm{N}^{\prime}, \mathrm{N}^{\prime}-\right.$ tetrakis (2-pyridylmethyl) octane diamine) by a series of nucleophiles, viz. thiourea (TU), L-cystein (LCYST), and glutathione (GLT) were investigated in $0.2 \mathrm{M} \mathrm{NaClO}_{4}$ ionic strength. The reactions were studied under pseudo-first order conditions at different temperatures and nucleophile concentrations. Reactions involving glutathione and L-cysteine were investigated using UV-Vis spectrophotomer while the faster reactions of thiourea were monitored on the stopped-flow spectrofluorimeter. Second order rate constants $\left(\mathrm{M}^{-1} \mathrm{~s}^{-1}\right)$ at $298 \mathrm{~K}$ are $0.194,0.567$, and 1.505 for GLT, L-CYST, and TU, respectively. The activation parameters obtained for the three nucleophiles in the same order of GLT, L-CYST, and TU, are $\Delta \mathrm{H}^{\neq}\left(\mathrm{kJ} \mathrm{mol}^{-1}\right)$ : 58.0, 13.0, 41.6 and $\Delta \mathrm{S}^{\neq}\left(\mathrm{J} \mathrm{K}^{-1} \mathrm{~mol}^{-1}\right)$ : -63.6, -206.1 and -101.8, respectively.
\end{abstract}

Keywords: 2-pyridylmethyl, platinum, substitution, kinetics, activation parameters

\section{Introduction}

Studies on the coordination chemistry of nitrogen based ligands and their corresponding transition metal complexes, has led to discovering their potentials of being used in various applications in medicine, agriculture, and catalysis among others [1-7]. The Rosenberg's discovery of the anti-tumour properties of cisplatin $\left(\right.$ cis- $\left[\mathrm{PtCl}_{2}\left(\mathrm{NH}_{3}\right)_{2}\right]$ in $1969^{[5]}$, encouraged further studies into the syntheses of several other platinum compounds with nitrogen based ligands which have been tested as potential anti-tumour drugs ${ }^{[8]}$. As efforts continued to find better alternatives to overcome the resistance developed to cisplatin and also its side effects, dinuclear and trinuclear platinum (II) complexes were synthesized. These complexes have the advantage of forming DNA adducts unlike their mononuclear ${ }^{[8-11]}$ counterparts. Ivanov and co-workers ${ }^{[12]}$ reported that while the dinuclear cis-triamine complexes of Pt (II) were cytostatically active to the growth of maize roots, their corresponding trans- complexes did not exhibit cytostatic effect.

It was recently shown that novel dinuclear Pt (II) complexes with a tetradentate ligand showed significant anti-tumour activities against some cell lines with one of the complexes actually showing better activity than carboplatin ${ }^{[13]}$. Some $\alpha$-diimine nickel and palladium complexes have been shown to be highly active catalysts for olefin oligomerisation and polymerisation reactions. Their activities have been attributed to the unique donor ability of the $\alpha$-diimine ligands in the complexes ${ }^{[3]}$.

Metal ions like $\mathrm{Pt}(\mathrm{II}), \mathrm{Pd}(\mathrm{II}), \mathrm{Ni}(\mathrm{II})$, and $\mathrm{Au}(\mathrm{II})$ have a $\mathrm{d}^{[8]}$ configuration and mostly form square planar compounds ${ }^{[14]}$. Complexes of platinum have in particular attracted extensive research because they form more stable planar complexes. For decades more effort has been directed to investigations on the kinetics and mechanisms of their reactions ${ }^{[15-18]}$, with most studies focused on ligand substitution at square-planar centres of $d^{[8]}$ transition metal ions such as platinum(ll) and palladium(II) ${ }^{[19]}$. These studies are largely connected to understanding the mechanisms of their activities as homogeneous catalysts and anti-tumour drugs ${ }^{[20-22]}$. Desigan and Jaganyi ${ }^{[23]}$ studied the substitution of the chloride and the aqua ligands from mononuclear platinum (ll) amine complexes, $[\mathrm{Pt}(\operatorname{dien}) \mathrm{Cl}] \mathrm{Cl},\left[\mathrm{Pt}(\mathrm{en}) \mathrm{NH}_{3} \mathrm{Cl}\right] \mathrm{Cl}$, 
$\left[\mathrm{Pt}(\right.$ dien $\left.)\left(\mathrm{OH}_{2}\right)\right]\left(\mathrm{ClO}_{4}\right)_{2}$, and $\left[\mathrm{Pt}(\mathrm{en})\left(\mathrm{NH}_{3}\right)\left(\mathrm{OH}_{2}\right)\right]\left(\mathrm{ClO}_{4}\right)_{2}$ with a series of nucleophiles including TU, DMTU, TMTU, $\mathrm{I}^{-}$, and $\mathrm{SCN}^{-}$. While the rate of substitution decreased with increased steric bulk of the nucleophiles, it increased with increased chelation in the complexes.

The reactivity and thermodynamic stability of dinuclear complex $\quad\left[\left\{\text { trans-PtCl}\left(\mathrm{NH}_{3}\right)_{2}\right\}\left(\mu-\mathrm{NH}_{2}\left(\mathrm{CH}_{2}\right)_{6} \mathrm{NH}_{2}\right)\right]^{2+}$ was shown to be independent of the state of one $\mathrm{Pt}(\mathrm{II})$ centre and that of the other ${ }^{[24]}$. Hoffmann and van Eldik ${ }^{[8]}$ investigated the influence of the bridging ligand in the substitution reactions of a series of dinuclear complexes of the type $\left[\mathrm{Pt}_{2}\left(\mathrm{~N}, \mathrm{~N}, \mathrm{~N}^{\prime}, \mathrm{N}^{\prime} \text {-tetrakis (2-pyridylmethyl)diamine }\right)\left(\mathrm{H}_{2} \mathrm{O}\right)_{2}\right]^{4+}$. Their results however showed that the reactivity of one $\mathrm{Pt}$ (II) centre is dependent on the nature of the other $\mathrm{Pt}(\mathrm{II})$ centre and also dependent on the Pt-Pt distance, a reflection of the bridging ligand chain length. Jaganyi and co-workers similaely investigated the influence of the bridging diamine ligands on the reactivities of $\mathrm{Pt}(\mathrm{II})$ complexes of the types $\left[\left\{\text { trans- } \mathrm{Pt}\left(\mathrm{H}_{2} \mathrm{O}\right)\left(\mathrm{NH}_{3}\right)_{2}\right\}_{2} \mathrm{NH}_{2}\left(\mathrm{CH}_{2}\right)_{\mathrm{n}} \mathrm{H}_{2} \mathrm{~N}\right]^{4+,}{ }^{[25]}, \quad\left[\left\{\mathrm{Pt}\left(\mathrm{H}_{2} \mathrm{O}\right)\right\}_{2}\right.$ $\left.\left(\mathrm{N}, \mathrm{N}, \mathrm{N}^{\prime}, \mathrm{N}^{\prime} \text {-tetrakis(2-pyridylmethyl)-N( } \mathrm{CH}_{2}\right)_{\mathrm{n}} \mathrm{N}\right]^{4+}, \quad[26]$, and $\left[\left\{\mathrm{Pt}\left(\mathrm{H}_{2} \mathrm{O}\right)\right\}_{2}\left(\mathrm{~N}, \mathrm{~N}, \mathrm{~N}^{\prime}, \mathrm{N}^{\prime}\right.\right.$-tetrakis(2-pyridylmethyl)-trans-1,4cyclohexyldiamine $]^{4+,}$ [27]. Their results showed that the reactivities of the $\mathrm{Pt}$ (II) complexes decrease with increase diamine chain length.

The effect of cyclometallation on the rates of reactions of $\mathrm{Pt}$ (II) complexes have also been variously demonstrated in different studies ${ }^{[28-33]}$. Acceleration of the reaction rates was explained in terms of $\sigma$-donor, $\pi$-acceptor, and trans effects of the Pt-C bonded ligands. This study reports further investigations on the effect of the nature of different nucleophiles as entering ligands on substitution reactions of $\left[\mathrm{Pt}_{2}\left(\mathrm{~N}, \mathrm{~N}, \mathrm{~N}^{\prime}, \mathrm{N}^{\prime}\right.\right.$-tetrakis (2pyridylmethyl) octanediamine) $\left.\left(\mathrm{H}_{2} \mathrm{O}\right)_{2}\right]\left(\mathrm{ClO}_{4}\right)_{4}$.

\section{Experimental \\ Chemicals}

Sodium hydroxide, perchloric acid and sodium perchlorate were supplied by Rochelle Chemicals. Silver perchlorate, Lcysteine (L-Cyst), thiourea(TU) and glutathione(GLUT) were all purchased from Fluka and used without further purification. N,N,N',N'-Tetrakis 2-pyridylmethyl) octanediamine as well as its chloro- and aqua-palladium(II) complexes were synthesised and characterised as reported in the literature ${ }^{[20,34]}$.

\section{Preparation of the aqua- metal complexes for kinetic studies}

The solution of the aqua complex (scheme 1) was prepared by dissolving a known amount of the chloro platinum complex, $\left[\mathrm{Pt}_{2}(\mathrm{~L}) \mathrm{Cl}_{2}\right]\left(\mathrm{ClO}_{4}\right)_{2}$ in $0.001 \mathrm{M}$ perchloric acid and then adding stoichiometric excess (with respect to the chloride) of $\mathrm{AgClO}_{4}$ (150-200\%). The mixture was stirred overnight at $40-50{ }^{\circ} \mathrm{C}$. Precipitated silver chloride was removed by filtration through a $0.45 \mu \mathrm{m}$ nylon membrane filter using a Millipore filtration apparatus. The $\mathrm{pH}$ of the solution was adjusted to $\mathrm{pH} 10-11$ via careful addition of $0.1 \mathrm{M} \mathrm{NaOH}$. This resulted in the precipitation of a gelatinous solid, $\mathrm{Ag}_{2} \mathrm{O}$ which was then filtered off through the $0.45 \mu \mathrm{m}$ nylon membrane. The process was repeated to make sure the $\mathrm{Ag}_{2} \mathrm{O}$ was completely removed. The $\mathrm{pH}$ of the resulting solution was adjusted to 2.0 by careful addition of perchloric acid $(10.6 \mathrm{M})$. The colourless solution obtained was diluted with $0.01 \mathrm{M} \mathrm{HClO}_{4}$ to afford the desired complex concentrations for the aqua analogue of the initial chloro complex.

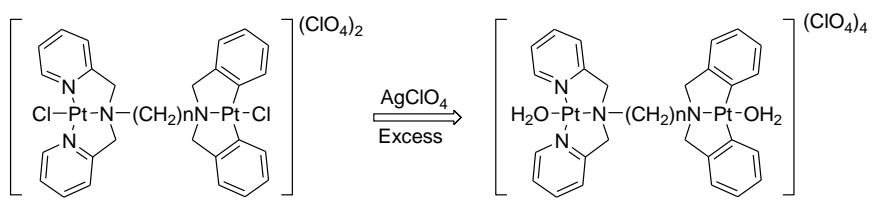

Scheme 1: Preparation of the aqua complex of N

This aquation of the chloro platinum complex $\left[\mathrm{Pt}_{2}(\mathrm{~L}) \mathrm{Cl}_{2}\right]$ $\left(\mathrm{ClO}_{4}\right)_{2}$, was performed in order to replace the coordinated chlorides in the complex by water molecules. The substitution of these water molecules by the three nucleophiles, thiourea, glutathione and L-cysteine (structures shown in Figure 1) was then kinetically investigated.<smiles>NC(=S)OCCCCCCCCCC(N)C(=O)O</smiles>

Fig 1: Structures of the nucleophiles used for the substitution reactions

\section{Preparation of nucleophile solutions for kinetic studies}

The stock solutions of the three nucleophiles, thiourea (TU), glutathione (GLT) and L-cystine (L-CYST) were prepared by dissolving required amount of each nucleophile in a minimum amount of $0.2 \mathrm{M} \mathrm{NaClO}_{4}$ and then made up to the $100 \mathrm{ml}$ mark in a standard volumetric flask. Each stock solution has a concentration that is approximately 100 times greater than that of the Platinum complex. The stock solution of the nucleophile was diluted to give the desired concentrations for kinetic studies.

\section{Kinetic studies}

All the kinetic studies were done using the Shimadzu UV2501-PC UV-VIS spectrophotometer for the relatively slow reactions and the HITECH- Scientific SF-61DX2 Single Mixing Stopped Flow spectrofluorimeter for the fast reactions. All substitution reactions were carried out under pseudo-first order conditions (nucleophile concentrations at least 10 times higher than that of the platinum(II) complex), and at ionic strength of $0.2 \mathrm{M} \mathrm{HClO} / \mathrm{HaClO}_{4}$. Constant temperature was maintained with a Peltier 240A temperature regulator attached to the UV-Vis spectrophotometer and by circulating water at the desired temperature from a Churchill thermocirculator around the sample holder of the stoppedflow equipment.

In order to determine the appropriate wavelengths for the kinetic studies, spectral scans of solutions of each of the $\mathrm{Pt}(\mathrm{II})$ complex and the nucleophile were recorded between 200 and $1100 \mathrm{~nm}$ on the UV-Vis spectrophotometer. Repeated scans of a mixture of solutions of both were then recorded at 5 minutes interval until no further changes could be observed in the absorption spectra indicating that the reaction has reached 
completion. The kinetics of reactions that reached completion within seconds or very few minutes were monitored on the stopped-flow spectrofluorimeter while those requiring longer times were performed using the Shimadzu UV-Vis spectrophotometer. Individual solutions of the $\mathrm{Pt}(\mathrm{II})$ complex and the nucleophiles were allowed to equilibratenat the desired temperatures before being mixed together to initiate the reactions.

The concentrations used for each nucleophile was between 20 and 100 times greater than that of the platinum complex while temperatures were varied between 25 and $35{ }^{\circ} \mathrm{C}$. Kinetic studies involving thiourea were performed on the stopped flow instrument and at a fixed wavelength of $267 \mathrm{~nm}$. Those involving L-Cysteine and glutathione were performed using the UV-Visible spectrophotometer and at single wavelengths of $270 \mathrm{~nm}$ and $267 \mathrm{~nm}$ respectively.

\section{Results and discussion}

The substitution of the aqua moieties from the aquated dinuclear platinum-octane complex, (Dipt.1,8) by neutral nucleophiles, thiourea (TU), glutathione (GLT) and Lcysteine (CYST), followed single exponential decay curves. Figure 2(a) shows a typical stopped-flow single exponential fit for the TU reaction while Figure 2(b) shows a typical firstorder linear regression plot for the reaction of GLT. The observed pseudo-first order rate constants, $\mathrm{k}_{\mathrm{obs}}$, for the TU reaction, were then obtained from the single exponential fits using the kinetic software of the stopped-flow equipment. The reaction can be represented by equation (1) below:

$\left[\mathrm{H}_{2} \mathrm{O}-\mathrm{Pt}_{1}-\mathrm{L}-\mathrm{Pt}_{2}-\mathrm{OH}_{2}\right]^{4+}+2 \mathrm{TU} \stackrel{k_{1}}{\longrightarrow} \quad\left[\mathrm{TU}-\mathrm{Pt}_{1}-\mathrm{L}-\mathrm{Pt}_{2}-\mathrm{TU}\right]^{2+}+2 \mathrm{H}_{2} \mathrm{O}$

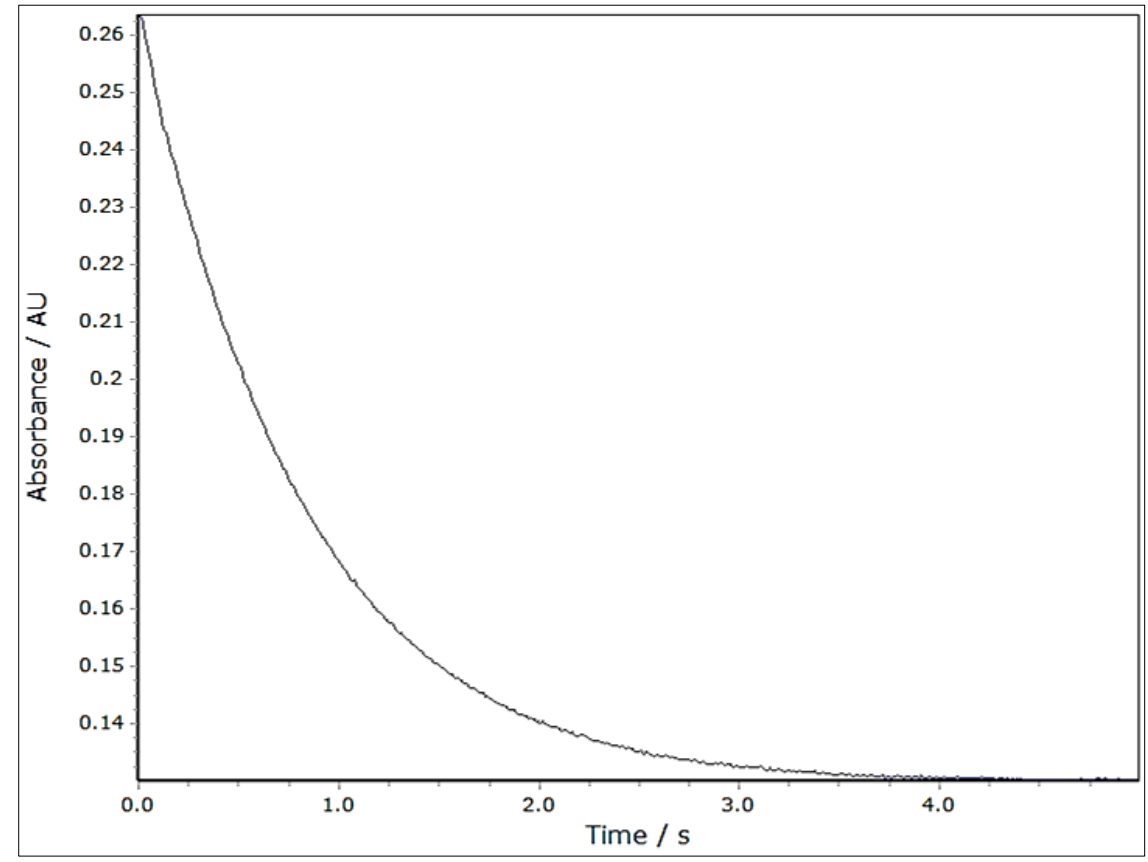

(a)

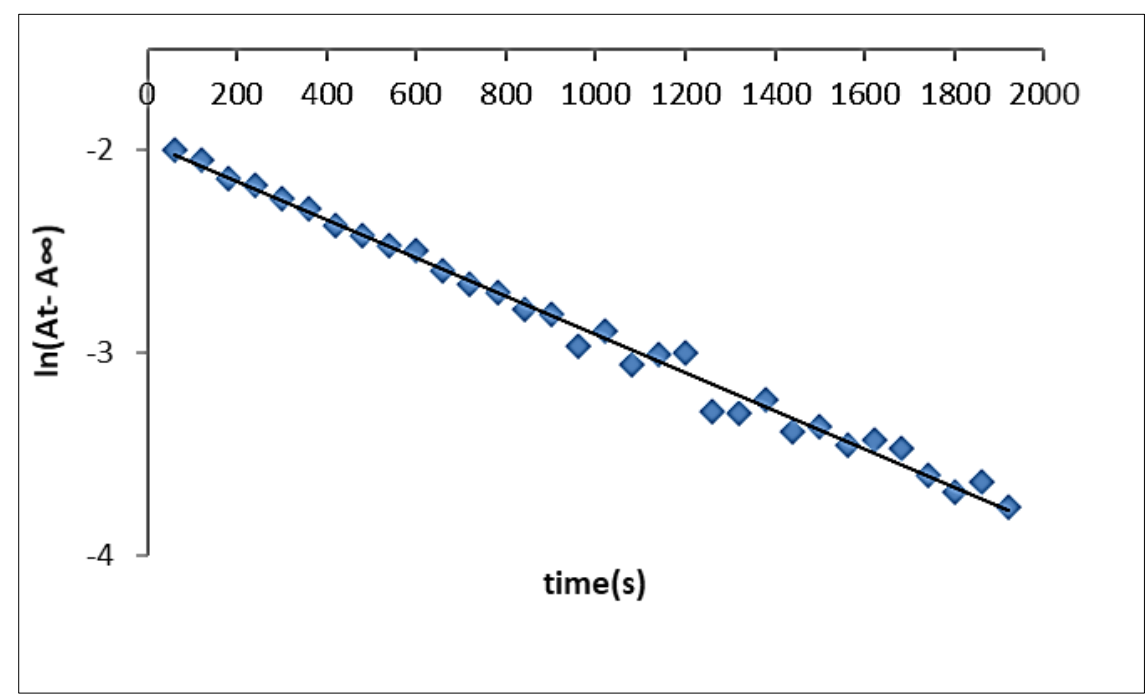

(b)

Fig 2: (a) Single exponential fit for the reaction of DiPt 1,8-aqua with thiourea; [DiPt 1, 8] = $1.0 \times 10^{-4}$, [TU] $=8.0 \times 10^{-3} \mathrm{M}, \mathrm{I}=0.2 \mathrm{M} \mathrm{NaClO} 4$, $\mathrm{T}=308 \mathrm{~K}$ (b) Linear Regression plot for the reaction between Dipt.1, 8-aqua complex and Glutathione; [DiPt 1,8$]=1.0 \mathrm{x} 10^{-4} \mathrm{M},[\mathrm{GLT}]=4.0$ x $10^{-3} \mathrm{M}, \mathrm{I}=0.2 \mathrm{M} \mathrm{NaClO}_{4}, \mathrm{~T}=298 \mathrm{~K}$. 
Conversely, $\mathrm{k}_{\mathrm{obs}}$ for reactions of GLT and L-CYST were obtained from slopes of the linear regression plots, a typical example of which is seen in Figure 2(b). These $\mathrm{k}_{\mathrm{obs}}$ values represent averages of three to four runs at each nucleophile concentration.

The calculated pseudo first order rate constants, $\mathrm{k}_{\mathrm{obs}}$, were plotted against the concentration of the incoming nucleophiles and the second order rate constants, $\mathrm{k}_{2}$, were determined from the slopes of such plots.

Table $1\left(\mathrm{a}, \mathrm{b}\right.$, and $\mathrm{c}$ ) shows the values of $\mathrm{k}_{\mathrm{obs}}$ and $\mathrm{k}_{2}$ for the three nucleophiles and a typical plot of $k_{\text {obs }} \mathrm{vs}[\mathrm{Nu}]$ is shown in Figure 3. Plots of $\mathrm{k}_{\mathrm{obs}} \mathrm{vs}[\mathrm{Nu}$ ] for all the three nucleophiles were linear with positive slopes as illustrated in Figure 4. Since there was no significant intercept on the $\mathrm{Y}$ axis, it was concluded that the reverse reaction involving substitution of the nucleophile by water was either too slow to make a significant contribution on the $\mathrm{k}_{\mathrm{obs}}$ value or it was completely absent. Therefore, $\mathrm{k}_{\mathrm{obs}}$ can be represented by the rate law given by

$\mathrm{k}_{\mathrm{obs}}=\mathrm{k}_{2}[\mathrm{Nu}] \quad$ where $\mathrm{Nu}=$ GLT, L-CYST

Table 1: Pseudo first order, $\mathrm{k}_{\mathrm{obs}}$ and second- order rate constants, $\mathrm{k}_{2}$, for the reactions of the DiPt-1, 8 complex with the three nucleophiles (a) TU, (b) GLT, and (c) L-CYST

a) $\mathbf{T U}$

\begin{tabular}{|c|c|c|c|c|c|}
\hline \multicolumn{6}{|c|}{$k_{\text {obs }}, s^{-1}$} \\
\hline$[\mathrm{TU}] \times \mathbf{1 0}^{-2}, \mathrm{M}$ & $298 K$ & $300 \mathrm{~K}$ & 303K & 305K & 308K \\
\hline 0.20 & 0.097 & 0.101 & 0.109 & 0.113 & 0.120 \\
\hline 0.40 & 0.101 & 0.105 & 0.113 & 0.118 & 0.126 \\
\hline 0.60 & 0.103 & 0.109 & 0.116 & 0.124 & 0.132 \\
\hline 0.80 & 0.106 & 0.112 & 0.121 & 0.128 & 0.136 \\
\hline 1.00 & 0.109 & 0.115 & 0.125 & 0.131 & 0.143 \\
\hline $\mathrm{k}_{2}, \mathrm{M}^{-1} \mathrm{~s}^{-1}$ & 1.51 & 1.81 & 2.00 & 2.32 & 2.76 \\
\hline
\end{tabular}

b) GLT

\begin{tabular}{|c|c|c|c|c|c|}
\hline \multicolumn{6}{|c|}{$\mathbf{k}_{\text {obs }} \times 10^{-3}, \mathrm{~s}^{-1}$} \\
\hline$\left[\right.$ GLT] $\times 10^{-2}, \mathrm{M}$ & 298K & $300 \mathrm{~K}$ & 303K & $305 K$ & $308 K$ \\
\hline 0.20 & 0.70 & 0.80 & 0.90 & 1.31 & 1.22 \\
\hline 0.40 & 1.19 & 1.30 & 1.57 & 1.86 & 1.98 \\
\hline 0.60 & 1.53 & 1.81 & 2.02 & 2.72 & 2.91 \\
\hline 0.80 & 1.89 & 2.30 & 2.64 & 3.43 & 3.75 \\
\hline 1.00 & 2.29 & 2.79 & 3.34 & 4.11 & 4.72 \\
\hline $\mathrm{k}_{2}, \mathrm{M}^{-1} \mathrm{~s}^{-1}$ & 0.194 & 0.249 & 0.297 & 0.359 & 0.439 \\
\hline
\end{tabular}

\section{c) L-Cyst}

\begin{tabular}{|c|c|c|c|c|c|}
\hline & \multicolumn{5}{|c|}{$\mathbf{k}_{\mathbf{o b s}} \mathbf{x} \mathbf{1 0}^{-\mathbf{3}}, \mathbf{s}^{-1}$} \\
\hline$[L-C Y S T] \mathbf{~ 1 0} \mathbf{~}^{-2}, \mathbf{M}$ & $\mathbf{2 9 8 K}$ & $\mathbf{3 0 0 K}$ & $\mathbf{3 0 3 K}$ & $\mathbf{3 0 5 K}$ & $\mathbf{3 0 8 K}$ \\
\hline 0.20 & 1.11 & 1.20 & 1.21 & 1.41 & 1.36 \\
\hline 0.40 & 2.28 & 2.31 & 2.41 & 2.61 & 2.75 \\
\hline 0.60 & 3.35 & 3.52 & 3.57 & 4.13 & 4.01 \\
\hline 0.80 & 4.62 & 4.79 & 4.88 & 5.29 & 5.58 \\
\hline 1.00 & 5.61 & 5.82 & 6.19 & 6.61 & 6.86 \\
\hline $\mathrm{k}_{2}, \mathbf{M}^{-1} \mathrm{~s}^{-1}$ & 0.567 & 0.586 & 0.621 & 0.654 & 0.692 \\
\hline
\end{tabular}

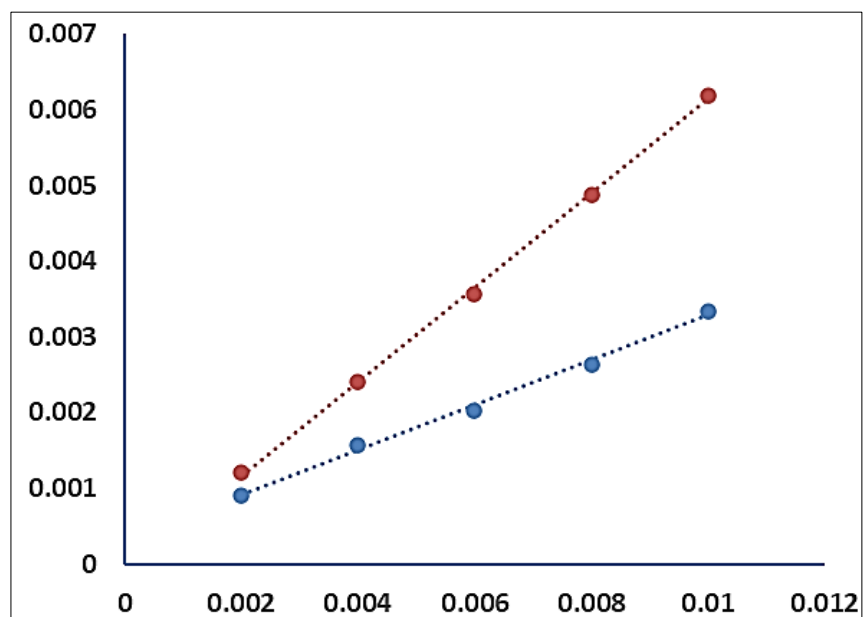

(a)

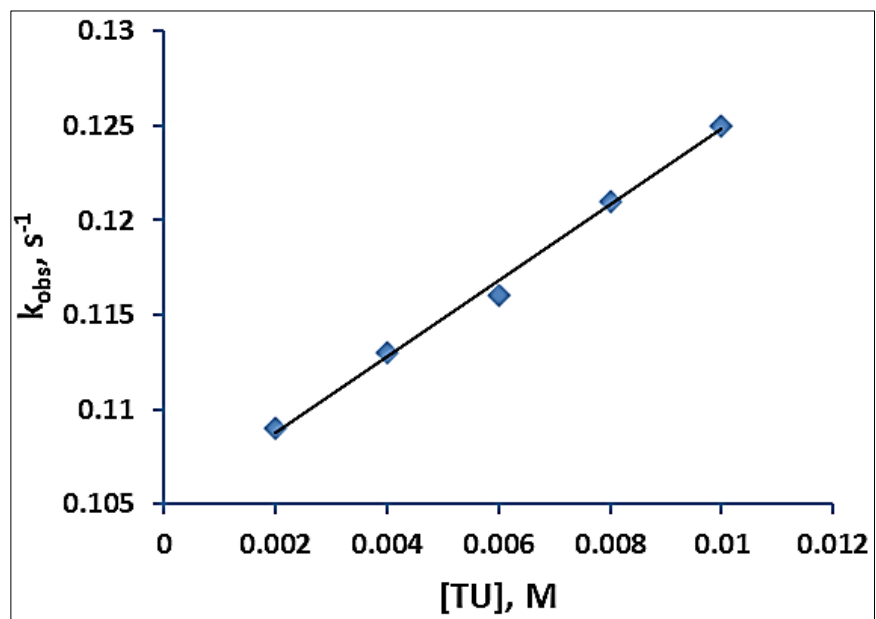

(b)

Fig 4: Plots of $\mathrm{k}_{\mathrm{obs}} \mathrm{vs}[\mathrm{Nu}]$ for the substitution reaction between DiPt-1,8 and (a) GLT \& L-CYST and (b) TU at $303 \mathrm{~K}$ 
Substitution reactions with TU, GLT, and L-CYST were performed at $\mathrm{pH} 2$ where the complexes exist in their diaqua form, and protonation of the TU can be ruled out as reported by Elding et al. ${ }^{[30]}$. The substitution reaction with TU is considerably faster than with GLT and L-CYST, and this is due to the fact that TU is a stronger nucleophile than GLT and L-CYST $[8,23,33]$. Also the order of reactivity of the nucleophiles (TU > L-CYST > GLT) can be linked with their bulkiness, i.e. steric hindrance as seen in Figure 1. This supports associative substitution mechanism typical of square planar complexes.

However for the reaction of $\mathrm{TU}$, the intercept, even though low, was noticeable and cannot be neglected. For this type of substitution reaction where there is an intercept, $\mathrm{k}_{\text {obs }}$ can be represented by: $\mathrm{k}_{\mathrm{obs}}=\mathrm{k}_{1}+\mathrm{k}_{2}$ [TU]

where $\mathrm{k}_{1}$ is given by the intercept of the plot of $\mathrm{k}_{\mathrm{obs}} \mathrm{vs}$ [TU]. Jaganyi and Reddy ${ }^{[23]}$ reported $\mathrm{k}_{2}$ values of $28.31 \mathrm{M}^{-1} \mathrm{~s}^{-1}$ and $8.02 \mathrm{M}^{-1} \mathrm{~s}^{-1}$ for the substitution of the aqua ligand by $\mathrm{TU}$ in mononuclear complexes $\left[\mathrm{Pt}(\right.$ dien $\left.)\left(\mathrm{OH}_{2}\right)\right]\left(\mathrm{ClO}_{4}\right)_{2}$ and $\left[\mathrm{Pt}(\mathrm{en})\left(\mathrm{NH}_{3}\right)\left(\mathrm{OH}_{2}\right)\right]\left(\mathrm{ClO}_{4}\right)_{2}$, respectively, in $0.2 \mathrm{M} \mathrm{NaClO}_{4}$. In their studies, plots of $\mathrm{k}_{\mathrm{obs}} \mathrm{vs}$ [TU] were linear without intercepts. In another study, van Eldik et al. ${ }^{[26]}$ reported similar observation but with $\mathrm{k}_{2}$ value of $572 \mathrm{M}^{-1} \mathrm{~s}^{-1}$ in $0.02 \mathrm{M}$ $\mathrm{LiSO}_{3} \mathrm{CF}_{3}$ for the simultaneous substitution of the two aqua ligands in $\left[\mathrm{Pt}_{2}\left(\mathrm{H}_{2} \mathrm{O}\right)_{2}\left(\mathrm{~N}, \mathrm{~N}, \mathrm{~N}^{\prime}, \mathrm{N}^{\prime}\right.\right.$-tetrakis (2-pyridylmethyl) octanediamine] $\left(\mathrm{CF}_{3} \mathrm{SO}_{3}\right)_{4}$ by $\mathrm{TU}$. Our Pt (II) complex is similar to the one investigated by van Eldik et al. ${ }^{[26]}$ except for different counter ions and the media for kinetic studies which differ. In the earlier studies ${ }^{[26]}$, linear plots of $\mathrm{k}_{\mathrm{obs}}$ against nucleophile concentration were without intercepts while in our case, similar linear plots gave intercepts. We can attribute the intercepts to medium effect, i.e. a mediumassisted ligand exchange process earlier reported ${ }^{[35]}$. The intercept could also be as a result of possible reverse reaction in which the displaced water molecule substitutes the TU again with a reaction rate constant given by $\mathrm{k}_{1}$.

The temperature dependence of the substitution reactions was studied over a temperature range of 298 to $308 \mathrm{~K}$. Application of the transition state theory and some thermodynamic relationship to Arrhenius equation leads to the Eyring equation given by

$\operatorname{Ln}\left(\mathrm{k}_{2} / \mathrm{T}\right)=-\left(\Delta \mathrm{H}^{\ddagger} / \mathrm{RT}\right)+\left[\mathrm{Ln}(\mathrm{kb} / \mathrm{h})+\Delta \mathrm{S}^{\neq} / \mathrm{R}\right]$

$\operatorname{Ln}\left(\mathrm{k}_{2} / \mathrm{T}\right)=-\left(\Delta \mathrm{H}^{\ddagger} / \mathrm{RT}\right)+\left(23.76+\Delta \mathrm{S}^{\neq} / \mathrm{R}\right)$

From equation (2), a plot $\mathrm{Ln}\left(\mathrm{k}_{2} / \mathrm{T}\right)$ against $1 / \mathrm{T}$ is expected to be linear with a negative slope. The activation parameters, $\Delta \mathrm{H}^{\ddagger}$ (enthalpy of activation) and $\Delta \mathrm{S}^{\ddagger}$ (entropy of activation), can then be calculated from the slope and intercept, respectively. Such plots for the three nucleophiles are shown in Figure 5 and the corresponding activation parameters in Table 2.

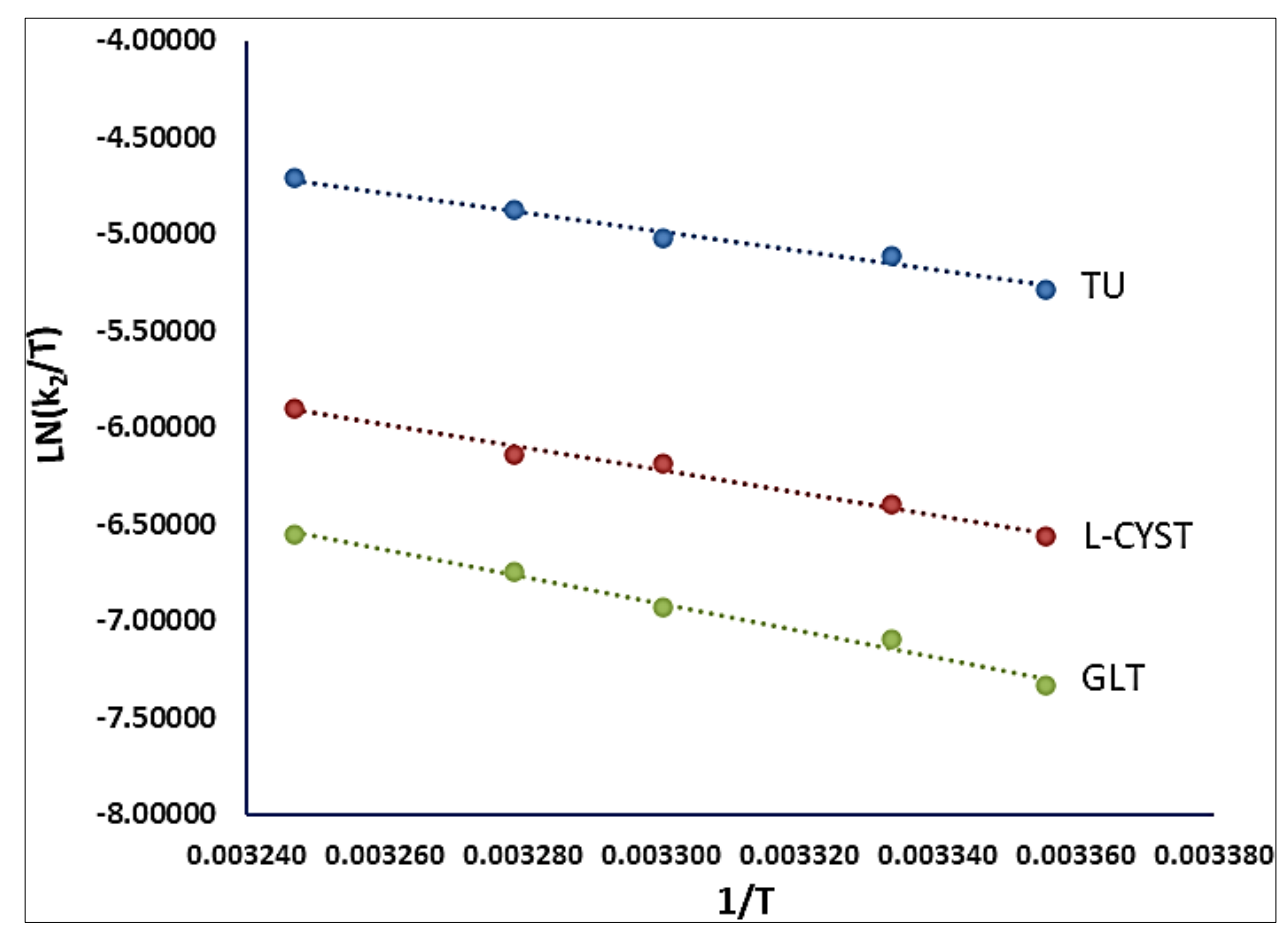

Fig 5: Plot of $\operatorname{Ln}\left(\mathrm{k}_{2} / \mathrm{T}\right)$ vs 1/T for the reaction of the aquated complex DiPt.1,8 with the three nucleophiles viz. TU, L-CYST and GLT

Table 3: Summary of activation parameters obtained for the displacement of the coordinated water molecules by TU, L-CYST AND GLT: $\mathrm{I}=0.2 \mathrm{M}\left(\mathrm{NAClO}_{4}\right)$.

\begin{tabular}{|c|c|c|}
\hline Nucleophile & $\Delta \mathbf{H}^{\ddagger}\left(\mathbf{K J} \mathbf{~ m o l}^{\mathbf{1}}\right)$ & $\Delta \mathbf{S}^{\ddagger}\left(\mathbf{J ~ K ~ K}^{-\mathbf{1}} \mathbf{M o l}^{\mathbf{1}}\right)$ \\
\hline TU & 41.57 & -101.81 \\
\hline L-CYST & 12.98 & -206.12 \\
\hline GLT & 58.02 & -63.55 \\
\hline
\end{tabular}

Since $\Delta \mathrm{H}^{*}$ is a measure of the standard enthalpy difference between the transition state and the ground state of the reactants it is therefore expected that the higher the activation enthalpy value, the lower the rate of the reaction. This expectation must however be applied with caution as $\Delta \mathrm{H}^{\ddagger}$ is not always directly related to the rate of reactions. The negative values of the activation entropies show that the transition state is relatively stable and of increased coordination number ${ }^{[31]}$. This observation further supports an associative substitution mechanism. Generally substitution reactions of square planar $\mathrm{Pt}(\mathrm{II})$ complexes proceed according to an associative mechanism and therefore should have a negative intrinsic $\Delta \mathrm{S}^{*}$ values as a result of bond formation at the transition state.

\section{Conclusions}

The different rate constants obtained for the substitution of the aqua ligand in DiPt.1,8 in this study has demonstrated 
how the nature of the entering ligand influence substitution in square planar complexes. The effect of steric hindrance has also been shown clearly as the rate of the reaction is lowered with increasing size of the nucleophile. These results as well as the negative entropies of activation obtained, are as expected in associative substitution reactions. When compared to earlier reports ${ }^{[8,26]}$, this study has in addition shown the medium effect as we noticed different reaction rates of the same complex in its reactions with TU in different media.

\section{Acknowledgement}

The authors gratefully acknowledge University of Botswana Research Committee for financial assistance.

\section{References}

1. Kalinowski DS, Richardson DR. Future of ToxicologyIron Chelators and Differing Modes of Action and Toxicity: The Changing Face of Iron Chelation Therapy Chem. Res. Toxicol. 2007; 20(5):715-720.

2. Hider RC, Zhou T. The Design of Orally Active Iron Chelators. Annals of the New York Academy of Sciences. 2005; 1054:141-154.

3. Sundaravajan G, Homogeneous catalyst for polymerisation of olefins in: Catalysis, principles and applications. Narosa Publishing House. New Delhi, 2002, 317-318.

4. Green M. Organometallic chemistry. Royal society of chemistry. UK, 2001, 364-368.

5. Rosernberg B, Van Champ L, Trosko JE, Mansour VH. Platinum compounds: a new class of potent antitumour agents. Nature. 1969; 22:385-386.

6. Cleare MJ, Hoeschele JD. Anti-tumour Platinum Compounds relationship between structure and activity Platinum Met. Rev. 1973; 17:2-13.

7. Campos Caipa MA. PhD Thesis; Nitrogen Based Ligands: synthesis, coordination chemistry and transition metal catalysis, 2005, 37-45.

8. Hofmann A, van Eldik R. Thermodynamic and kinetic study of the interaction between the Pt (II) centres in $\left[\mathrm{Pt}_{2}\right.$

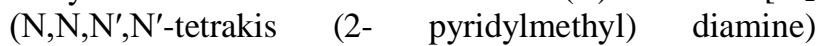
$\left.\left(\mathrm{H}_{2} \mathrm{O}\right)_{2}\right]^{4+}$. Influence of the bridging ligand Dalton Trans, 2003, 2979-2985.

9. Wong E, Giandomenico CM. Current status of platinumbased antitumor drugs. Chem, Rev. 1999; 99:2451-2466.

10. Farrell N. DNA Binding and Chemistry of Dinuclear Platinum Complexes Comments Inorg. Chem. 1994; 16:373-389.

11. Farrell N, Appleton TG, Qu Y, Roberts JD, Soarres Fontes AP, Skov KA et al. Effects of Geometric Isomerism and Ligand Substitution in Bifunctional Dinuclear Platinum Complexes on Binding Properties and Conformational Changes in DNA. Biochemistry. 1995; 34:15480-15486.

12. Ivanov VB, Bystrova EI, Yakovlev KI, Rozhkovan ND, Stetsenko AI, Adamov OM et al; Growth inhibiting and cytostatic activities of triamine platinum II complexes with heterocyclic amines. Akad. Nauk. Ser. Biol. 1992; 6:898-907.

13. Gao CZ, Wang TS, Zhang Y, Chen J, Qian YX, Yang B, et al., Design, synthesis and in vitro cytotoxicity of novel dinuclear platinum (II) complexes with a tetradentate carrier ligand, App. Organo. Chem. 2015; 29(3):138-142.

14. Atwood JD. Inorganic and organometallic Reaction mechanisms, 2nd Ed, Wiley-VCH, 1997, 43-61.
15. Basolo F. Recollections of early studies on platinum (II) complexes related to Chatt's contributions to coordination chemistry, Coordination Chem. Reviews. 1996; 154:151161.

16. Cross RJ. Ligand substitution reactions of square-planar molecules, Chem. Soc. Reviews. 1985; 14:197-223.

17. Catallini L. The intimate mechanism of replacement in $\mathrm{d} 8$ square-planar complexes. Progress Inorg. Chem. 1970; 13:263-268.

18. Cross RJ. An Appraisal of Square-Planar Substitution Reactions. Advance. Inorg. Chem. 1989; 34:219-292.

19. Richens DT. Ligand substitution reactions at inorganic centers. Chem Rev. 2005; 105(6):1961-2002.

20. Fekl U, Goldberg KI. Homogeneous hydrocarbon $\mathrm{CH}$ bond activation and functionalization with platinum. Adv. Inorg. Chem. 2003; 54:259-320.

21. Lippert B. Cisplatin, Chemistry and Biochemistry of a leading Anticancer Drug. Wiley-VCH, Weinheim, 1999, 31-72.

22. Farrel N. Transition Metal Complexes as Drugs and Chemotherapeutic Agents, Kluwer Academic Publishers, Dordrecht, 1989, 291-315.

23. Reddy D, Jaganyi D. Does increased chelation enhance the rate of ligand substitution at Pt-II $(\mathrm{N}, \mathrm{N}, \mathrm{N})$ centres? A detailed kinetic \& mechanistic study. Transition Metal Chemistry. 2006; 31:792-800.

24. Davies MS, Thomas DS, Hegmans A, Berners-Price SJ, Farrell N. Kinetic and Equilibria Studies of the Aquation of the Trinuclear Platinum Phase II Anticancer Agent $\left[\left\{\text { trans-PtCl}\left(\mathrm{NH}_{3}\right)_{2}\right\}_{2}\left\{\mu\right.\right.$-trans- $\mathrm{Pt}\left(\mathrm{NH}_{3}\right)_{2}\left(\mathrm{NH}_{2}\left(\mathrm{CH}_{2}\right)_{6} \mathrm{NH}_{2}\right)$ $2\}]^{4+}$. Inorg. Chem. 2002; 41(5):1101-1109.

25. Jaganyi D, Munisamy VM, Reddy D. Role of bridging diamine linkers on the rate of ligand substitution in a series of dinuclear PtII complexes. Int. J. Chem. Kinet. 2006; 38(3):202-210.

26. Mambanda A, Jaganyi D, Hochreuther S, van Eldik R. Tuning the reactivity of chelated dinuclear $\mathrm{Pt}(\mathrm{II})$ complexes through a flexible diamine linker. A detailed kinetic and mechanistic study. Dalton Trans. 2010; 39(15):3595-3608.

27. Mambanda A, Jaganyi D. A kinetics and mechanistic study on the role of the structural rigidity of the linker on the substitution reactions of chelated dinuclear Pt (II) complexes. Dalton Trans. 2012; 41(3):908-920.

28. Schmulling M, Grove DR, Kotenvan G, van Eldik R, Veldman N, Spek LA. Comparative Rates of Ligand Substitution Reactions of $\mathrm{Pt}-\mathrm{C}$-Bonded Complexes in Aqueous Solution and the X-ray Crystal Structure of [Pt $\{\mathrm{C} 6 \mathrm{H} 3(\mathrm{CH} 2 \mathrm{NMe} 2) 22,6\}(\mathrm{OH} 2)][\mathrm{OSO} 2 \mathrm{CF} 3]$ Organom etallics. 1996; 15:1384-1391.

29. Schmulling M, Ryabov AD, van Eldik R. To What Extent can the Pt-C Bond of a Metallacycle Labilize the trans Position? A Temperature- and Pressure-dependent Mechanistic Study. Dalton Trans, 1994, 1257-1263.

30. Elding LI, Romeo R, Schmulling M, Ryabov AD, van Eldik R. Tuning of the reactivity of platinum (II) complexes through cyclometallation. A comment. Dalton trans, 1996, 1471-1473.

31. Jaganyi D, Reddy D, Gertenbach JA, Hoffmann A, van Eldik R. Role of chelate substituents and cis $\sigma$-effect on the rate of ligand substitution at $\mathrm{Pt}(\mathrm{N}-\mathrm{N}-\mathrm{N})$ and $\mathrm{Pt}(\mathrm{N}-\mathrm{N}-$ C) centres. Dalton trans, 2004, 299-304.

32. Hofmann A, Dahlenburg L, van Eldik R. Cyclometalated Analogues of Platinum Terpyridine Complexes: Kinetic Study of the Strong $\sigma$-Donor Cis and Trans Effects of 
Carbon in the Presence of a $\pi$-Acceptor Ligand Backbone, Inorg. Chem. 2003; 42:6528-6538.

33. Hakan E, Puchta R, van Eldik R. Synthesis, Characterization, Thermodynamic and Kinetic Properties of a New Series of Dinuclear PtII Complexes. Eur. J. Inorg. Chem, 2009, 1331-1338.

34. Mohamadou A, Gerard C. Synthesis and characterisation of zinc(ii) complexes of tripodal N7ligands involving pyridine and amine or amidenitrogen donors. Crystal structure of a zinc (ii) complex J. Chem. Soc. Daiton Trans, 2001, 3320-3328.

35. Oyetunji OA, Ramokongwa G, Becker CAL. Dynamics of the reactions of pentakis ( $t$-octylisocyanide) cobalt (II) complex with tryarylphosphines; J. Coord. Chem. 2013; $14: 2489-2498$. 